\title{
KRAJOBRAZNA I BIOLOŠKA RAZNOLIKOST KAO \\ PARADIGMA RAZVOJA POSEBNIH OBLIKA TURIZMA \\ U REGIONALNOM PARKU MOSLAVAČKA GORA
}

\author{
LANDSCAPE AND BIODIVERSITY OF THE MOSLAVINA GORA \\ REGIONAL PARK AS A PARADIGM FOR THE DEVELOPMENT \\ OF SPECIAL FORMS OF TOURISM
}

\author{
A. Vrsaljko, M. Santrić, Đ. Bunja
}

\section{SAŽETAK}

Moslavačka gora je 2011. godine proglašena drugim regionalnim parkom u Hrvatskoj, budući da ima regionalno značenje za očuvanje krajobrazne, biološke i geološke raznolikosti. U radu je dat kratak pregled krajobraznih posebnosti (voda, tala, reljefa, geomerfologije) i biološke raznolikosti (flora i fauna). Te posebnosti je potrebno valorizirati u turističkom pogledu, posebice ispitati mogućnosti implementacije posebnih oblika turizma $u$ zaštićenim područjima kao što su: Willdife tourism, Ecotourism, Adventure tourism, Nature based tourism u samom području parka, odnosno Agritourism and Ecoaritourism u i oko parka. Glavni cilj ovog istraživanja je testiranje posjetitelja regionalnog parka Moslavačka gora o krajobraznoj, geološkoj i biološkoj raznolikosti, u kojoj mjeri i na koji način ta raznolikost pridonosi njihovu posjetu, te koliko bi svojom raznolikošću mogla pridonijeti razvoju posebnih oblika turizma na Moslavačkoj gori. Upravo iznimno bogata krajobrazna, biološka i geološka raznolikost $\mathrm{s}$ pojedinačnim biološkim, krajobraznim (geološkim i geomorfološkim) atrakcijama privlači posjetitelje / ljubitelje prirode i na taj način pridonosi razvoju turizma Moslavačke gore. Istraživanje je provedeno preko on-line obrasca koji je osmišljen tako da ispita mogućnost razvoja posebnih oblika turizma na Moslavačkoj gori, pri čemu su odgovarale osobe koje su već posjetile regionalni park. Sudjelovala su 306 ispitanika, od toga 192 žene i 114 muškarca. Anketni upitnik se sastoji od 25 pitanja putem kojih se testiralo mišljenje ispitanika o krajobraznoj i biološkoj raznolikosti parka. 
A. Vrsaljko i sur.: Krajobrazna i biološka raznolikost kao paradigma razvoja posebnih oblika turizma u regionalnom parku Moslavačka gora

Dobiveni podaci na postavljena pitanja su potvrdili da je većina posjetitelja svjesna koliku biološku, krajobraznu i geološku baštinu ima Moslavina ( 90\% ispitanika), no kada je riječ o posebnostima pojedine baštine onda o tome vrlo malo ili ništa ne znaju. To nije začudilo jer smo temeljem odgovora na koji način su nešto saznali o Moslavačkoj gori dobili sljedeće odgovore: Internet (oko 60\%), prijatelji i znanici (oko 40\%), vodiči (oko 30\%), a tek onda putem promotivnih materijala i turističkih agencija. Ispitanici/posjetitelji naprosto žude za edukacijskim programima o krajobraznoj, biološkoj i geološkoj raznolikosti Moslavine kakvih nema u parku. Većina posjetitelja zna koliko je bogata i važna biološka, krajobrazna i geološka raznolikost, dok tek oko $50 \%$ posjetitelja zna da može posjetiti značajne lokalitete. S obzirom na to da je najmanji postotak posjetitelja upoznat $\mathrm{s}$ biološkom raznolikosti, većina njih želi proći edukacijske programe o flori i fauni Moslavačke gore. Nadalje, više od 50\% posjetitelja smatra da interakcija s prirodom na Moslavačkoj gori nije dobra (negativno za Ecotourism). Glede biološke raznolikosti 64,7\% ispitanika smatra da se na osnovi toga može razvijati Ecotourism, a 35,3\% Wildlife tourism, dok glede krajobrazne raznolikosti smatraju da se mogu razvijati Adventure tourism $(61,8 \%)$ i Nature Based tourism (38,2\%).

Istraživanja su pokazala da se pozornost treba prvenstveno usmjeriti na razvoj edukacijskih programa o krajobraznoj i biološkoj raznolikosti parka, odnosno posebnih oblika turizma koji se mogu odvijati u parku.

Ključne riječi: krajobraz, bioraznolikost, turizam, Regionalni park

\section{ABSTRACT}

Moslavačka gora was declared the second regional park in Croatia in 2011, since it has a regional significance for the preservation of landscape, biological and geological diversity. This paper gives a brief overview of landscape features (water, soil, relief, geomorphology) and biodiversity (flora and fauna). These special features need to be valorised by means of tourism and in particular it is necessary to explore the possibilities of implementing special forms of tourism in protected areas such as: wildlife tourism, ecotourism, adventure tourism, nature based tourism in the park itself, and Agritourism and Ecoagritourism in and around the park. The main objective of this research is to test the visitors of the Moslavačka Gora Regional Park on landscaping, geological and biological diversity, to what extent and how this diversity contributes to their visit, and how much it could contribute to the development of special forms of tourism on 
A. Vrsaljko i sur.: Krajobrazna i biološka raznolikost kao paradigma razvoja posebnih oblika turizma u regionalnom parku Moslavačka gora

Moslavačka Gora. Exceptionally rich in landscape, biological and geological diversity with individual biological and landscape (geological and geomorphological) features, it attracts visitors / nature lovers and thus contributes to the development of the Moslavačka Gora tourism. The research was carried out by an on-line form designed to examine the possibility of developing special forms of tourism in Moslavačka Gora, where the respondents were the persons who had already visited the regional park. 306 respondents participated, of which 192 women and 114 men. The survey questionnaire consisted of 25 questions by which the opinion of the respondents on the landscape and biodiversity of the park was tested.

The collected data confirm that most visitors are aware of the size of the biological, landscape and geological heritage of Moslavina (90\% of respondents), but when it comes to the particularities of a given heritage, little or nothing is known about it. This was not surprising as we got the following answers on Moslavačka Gora: Internet (about 60\%), friends and acquaintances (about $40 \%$ ), guides (around 30\%), and then only by promotional materials and travel agencies. The respondents/visitors simply craved for educational programs on the landscape, biological and geological diversity of Moslavina not existing in the park. Most visitors know how rich and important biological, landscape and geological diversity is, while only about $50 \%$ of visitors know that they can visit significant localities. Given that the smallest percentage of visitors are familiar with its biodiversity, most of them want to go through educational programs on the flora and fauna of Moslavačka Gora. Furthermore, more than $50 \%$ of visitors believe that interaction with nature on Moslavačka Gora is not good (negative for ecotourism). With regard to biodiversity, $64.7 \%$ of the respondents believe that ecotourism and $35.3 \%$ that wildlife tourism can be developed based on such biodiversity, while landscape diversity is suitable for adventure tourism (61.8\%) and nature based tourism $(38.2 \%)$.

The research has shown that attention should primarily be directed to the development of educational programs on landscape and biodiversity of the park, or special forms of tourism that can take place in the park.

Keywords: Landscape, Biodiversity, Tourism, Regional Park 
A. Vrsaljko i sur.: Krajobrazna i biološka raznolikost kao paradigma razvoja posebnih oblika turizma u regionalnom parku Moslavačka gora

\section{UVOD}

Moslavina kao subregija Hrvatske u kojoj se nalazi Regionalni park Moslavačka gora je sastavni dio velikog panonskog areala. Područje Moslavine, a posebice RP Moslavačka gora obiluje mnoštvom krajobraznih i bioloških raznolikosti što bi mogao biti temelj turističke ponude cijeloga kraja. Ekološke posebnosti moslavačkog kraja čine klima, vode, tla, reljef, geomorfologija, flora i fauna. Svaki od ovih čimbenika na jedinstven način pridonosi raznolikosti moslavačkog kraja, time i razvoju specifičnih oblika turizma, koji su u ovom dijelu Hrvatske u začecima. Krajobrazna i biološka raznolikost očuvana je na ovom području bez znatnog negativnog antropogenog utjecaja i ima nedvojbeno regionalnu važnost. Temeljni fenomen Moslavačke gore su šume, koje su ujedno i najljepši prirodni doprinos. Klimatski i pedološki čimbenici omogućili su veliko bogatstvo bjelogoričnih šuma. Najljepši ukras predstavljaju bjelogorične šume hrasta kitnjaka, bukve, graba, pitomog kestena, johe, breze i bora. Područje je premreženo brojnim potocima te različitom faunom koju čine jelen, srna, zec, divlja svinja, lisica, jazavac, kuna zlatica, škanjac, orao, jastreb, sova, brojne ptice pjevice, gmazovi, leptiri, kukci i sl.

U flori Moslavačke gore utvrđene su 242 biljne vrste, od kojih je 55 zaštićeno, dok su dvije vrste ugrožene na nacionalnoj razini i nalaze se u Crvenoj knjizi vaskularne flore Republike Hrvatske (Nikolić i Topić, 2005.). Moslavačka gora je faunistički gledano relativno siromašna izuzev ornitofaune koja broji 64 vrste ptica, među kojima i 18 ugroženih. Povijesno kulturna baština dodatno može pridonijeti valorizaciji parka za posebne oblike turizam (Cifrić, 2014.).

\section{PREGLED LITERATURE}

U samom čovjekovom kodu postoji neraskidiva veza s prirodom, odnosno upućenost na prirodu. Danas, kada čovjek živi i radi u stresnom okruženju možemo reći da je priroda „najblagotvorniji eliksir" za opuštanje. To su u prvom redu zaštićena područja, kao oaze netaknute prirode pogodna za posebne oblike turizma, gdje dolazi do fine interakcije posjetitelja i prirode u totalu (Smith \& Eadicton, 1992.; Cater, 1993.; Wearing \&Neil, 1999.; Holden, 2003.). Koristimo primjer Norveške gdje je došlo do značajnog povećanja broja nacionalnih parkova i ostalih zaštićenih područja, pri čemu trideset i tri nacionalna parka na kopnu čine oko osam posto kopna (Haukeland, 2011.). Od 2003. godine proglašeno je 8 nacionalnih parkova, 
A. Vrsaljko i sur.: Krajobrazna i biološka raznolikost kao paradigma razvoja posebnih oblika turizma u regionalnom parku Moslavačka gora

pri čemu koristi svoje parkove dvostruko, kroz funkciju za promicanje očuvanja prirode, odnosno funkciju povećanja prihoda od turizma i rekreacije (Hall \& Frost, 2012.). Općeprisutna je bojazan da učinci turizma mogu znatno djelovati na okoliš, prvenstveno na biljni i životinjski svijet, unatoč mjerama koje se poduzimaju kako bi se izbjeglo ugrožavanje već zaštićenih vrsta (Buckley, 2004.). Planinari gaze staze koje uništavaju vegetaciju i otkrivaju korijenje biljaka, što smanjuje otpornost biljaka na sve veće klimatske promjene (Haukeland, 2011.). Turizam u netaknutoj prirodi $\mathrm{s}$ jedinstvenim atrakcijama postao je u zadnje vrijeme brzorastući segment turističke industrije (Balmford et al., 2009.; Haegeli \& Pröbstl-Haider, 2016.; Haegeli, P. \& Pröbstl-Haider, U., 2016.). Upravljanje zaštićenim područjima time postaje sve izazovnije i zahtijeva holistički pristup da se postigne ravnoteža između određenih oblika turizma koji će zadovoljiti turiste uz minimiziranje mogućih sukoba u zaštićenim područjima. To ujedno predstavlja izazov pri izradi politika upravljanja zaštićenim područjima (Juutinen et al., 2011.; Lertwannawit \& Anuwichanont, 2011.). Wildlife tourism je važan oblik turizma (Higginbottom, 2004.a), a kao primjer promatranja divljih životinja dobiva na važnosti u Islandu (Granquist \& Nilsson, 2013.; Nilsson, 2012.). Wildlife tourism fascinira turiste i povećava interes za biljni i životinjski svijet, te tako može biti alat za pojačanu zaštitu u određenim staništima i zajednicama (McNeely, et al.,2004.), no isto tako može postići negativne učinke kao što su promjene u ponašanju ili fiziološke promjene promatranih životinja (Green \& Giese, 2004; Reynolds \& Braithwaite, 2001.). Fennell (2013.) smatra da je masovni turizam neodrživ oblik turizma, stoga zagovara alternativne oblike turizma koji su održivi.

\section{Pustolovni turizam}

Pustolovni turizam i turizam temeljen na prirodi dijele sličnosti, ali su različiti aspekti turizma. Pustolovni turizam je turizam koji je usmjeren na aktivnosti u prirodnom okruženju. To uključuje fizički izazov, edukaciju i kontakt s prirodom, a može biti jedan od tri tipa; malih razmjera tj. s mnogo obilježja ekoturizma (npr. promatranje ptica, ronjenje itd.); srednjih razmjera i sportski orijentiran (npr. kanu i rafting); i velikih razmjera u obliku masovnog turizma (npr. safari) (Newsome et al., 2013.). Glede Adventure tourism glavne aktivnosti uključuju planinarenje, penjanje po stijenama, ronjenje i plivanje, aktivnosti u vodi, trekking, avanturu na plaži, prirodne ljepote i avanturu divljih životinja (Dutta, \& Dutta, 2013). 
A. Vrsaljko i sur.: Krajobrazna i biološka raznolikost kao paradigma razvoja posebnih oblika turizma u regionalnom parku Moslavačka gora

Nature based tourism

Turizam temeljen na prirodi, kao što mu sam naziv kaže, vezan je isključivo za prirodu i ima poseban naglasak na poticanju razumijevanja i očuvanja prirodnog okoliša, osim što obuhvaća promatranje prirode kao primarni cilj. Ova vrsta turizma usredotočena je na promatranje abiotskih (neživih) dijelova okoliša, npr. stijene i krajobraz, kao i biotskih (živih) dijelova okoliša, npr. biljni i životinjski svijet. Harrison i Husbands (1996.) u svojoj knjizi navode da turizam temeljen na prirodi obuhvaća održivi pristup u kojem turizam donosi prednosti za turiste, lokalno stanovništvo i državu. Turizam temeljen na prirodi razlikuje se od Wildlife turizma jer ima širi fokus nego čisto promatranje divljači. Čitav okoliš primarni je fokus, ovu vrstu turizma preferiraju turisti koji dolaze na izlete $\mathrm{u}$ prirodu te holistički uživaju u cjelokupnom prirodnom okruženju. Cilj je unapređivati ovu vrstu turizma ali istovremeno imati na umu da bi vrlo lako moglo doći do masovnosti što nikako nije poželjno (Newsome et al., 2013.).

Wildlife turizam

Kvaliteta prirodnog područja temelji se na biološkim elementima, tj. biljnom i životinjskom svijetu koji igra glavnu ulogu u privlačenju turista u određene destinacije. Turisti u takvim područjima traže iskustvo koje će im omogućiti da istraže, bez obzira na vrijeme boravka u destinaciji, novi ekosustav i njegove stanovnike. Postoje razlike između posjetitelja, neki su entuzijasti, beskrajno žele istraživati biljni i životinjski svijet dok su drugi samo izletnici u okolna području, nedaleko od luksuznih hotela u kojima borave (Shackley, 1996.). Velik broj posjetitelja želi upoznati što širu okolicu, dok drugi dolaze prvenstveno radi zabave. Postoji puno različitih oblika wildlife turizma što se može vidjeti na primjerima u SAD-u; turisti mogu birati između promatranja obale na kojoj se nastanjuju različite vrste divljači, safari u Keniji, antarktičko krstarenje radi promatranja pingvina ili kitova te mnoštvo takvih oblika izleta ili putovanja. Porast broja wildlife turista u posljednjih nekoliko godina predstavlja fenomen (Ceballos-Lascurain, 1998.).

\section{Ekoturizam}

Primarni ciljevi ekoturizma su poticanje održivog korištenja prirodnih resursa uz istodobno njihovo očuvanje, održivo korištenje kulturnih dobara te poticanje ekonomskog razvoja i diversifikacije. Ceballos-Lascurain (1998.) smatra da bi na individualnoj razini trebalo dodati ulaganje u kvalitetu života 
A. Vrsaljko i sur.: Krajobrazna i biološka raznolikost kao paradigma razvoja posebnih oblika turizma u regionalnom parku Moslavačka gora

ljudi kroz učenje o prirodnom svijetu. Kroz dugi niz godina vodila se rasprava o tome kako na najbolji način definirati pojam ekoturizma jer se često miješa s drugim vrstama turizma (Fenel, 1999.)., ali to je točno samo ako se turizam odvija s velikom pažnjom. Honey (1999.) upućuje na to da stvarni ekoturizam ima sedam obilježja. To uključuje putovanje do prirodne destinacije, smanjen utjecaj na okoliš, podizanje ekološke svijesti, pružanje izravne financijske koristi za očuvanje prirodnih područja, pružanje financijske koristi za lokalno stanovništvo, poštivanje lokalne kulture, podržavanje ljudskih prava i demokracije. To su saželi Gaymans \& Hikes (1996.) u Five parameters of ecotoursm. Ekoturizam je zapravo putovanje u krhka, netaknuta i obično zaštićena prirodna područja, te nastoji imati malen utjecaj na okoliš (Newsome et al., 2013.). Posebno prihvatljivi oblici turizma su i eko parkovi koji koriste domicilne vrste biljaka i životinja kao atrakcije u prirodi ili pak u gastronomiji su agriturizam i ecoagriturizam (Vrsaljko and Viljac, 2015.; Vrsaljko and Čukelj, 2016.; Vrsaljko et al., 2017.).

\section{MATERIJAL I METODE}

Da bi se turizam uopće mogao razvijati, potrebno je valorizirati turistički destinaciju, temeljem toga privući turiste, dajući im ponudu koja će opravdati njihov dolazak. Prema tome, cilj ovog istraživanja je testirati posjetitelje regionalnog parka Moslavačka gora o krajobraznoj, geološkoj i biološkoj raznolikosti, u kojoj mjeri ta raznolikost pridonosi njihovu posjetu, te koliko bi svojom raznolikošću mogla pridonijeti razvoju turizma na Moslavačkoj gori. Pri sastavljanju anketnog upitnika obuhvaćena je sljedeća problematika:

1. Detekcija razloga dolazaka posjetitelja u park.

2. Percepcija posjetitelja o krajobraznoj, biološkoj i geološkoj raznolikosti parka.

3. Percepcija posjetitelja o pogodnosti parka za razvoj specifičnih oblika turizma.

Istraživanje je provedeno preko on-line obrasca koji je osmišljen tako da ispita mogućnost razvoja specifičnih oblika turizma na Moslavačkoj gori kako bi se došlo do spoznaje koliko su posjetitelji uopće upoznati s onim što ovaj regionalni park može pružiti. Anketu o razvoju različitih oblika turizma na Moslavačkoj gori, posjetitelji su ispunili preko on-line obrasca koji im je poslan putem linka te su pitanja postavljena tako da mogu odgovarati osobe koje su već posjetile regionalni park kako bi dobili uvid koliko su uopće ispitanici upoznati s prirodnom ljepotom ovoga kraja. Anketa o razvoju različitih oblika turizma na 
A. Vrsaljko i sur.: Krajobrazna i biološka raznolikost kao paradigma razvoja posebnih oblika turizma u regionalnom parku Moslavačka gora

Moslavačkoj gori sadrži 25 pitanja kojim su prikupljeni demografski podaci posjetitelja, podaci o mišljenju posjetitelja Regionalnog parka Moslavačka gora o krajobraznoj, geološkoj i biološkoj raznolikosti moslavačkog kraja, te koliko ta raznolikost pridonosi i koliko bi mogla pridonijeti razvoju turizma na „Moslavačkoj gori“. U istraživanju su sudjelovala 306 ispitanika, od toga 192 žene i 114 muškarca. Prikupljeni podaci obrađeni su kroz izračun postotnog udjela unutar pojedinog pitanja.

\section{REZULTATI I DISKUSIJA}

$\mathrm{Na}$ pitanje o učestalosti posjeta regionalnom parku $64,7 \%$ ispitanika je prvi put posjetilo park, a $35,3 \%$ dva ili više puta, što nas upućuje na nedovoljnu prepoznatljivost regionalnog parka što je zabrinjavajuće i na čemu valja ozbiljno poraditi. To je u prvom redu na rukovodstvu parka, turističkoj zajednici, županiji, Ministarstvu turizma i Ministarstvu kulture.

Glede razloga posjeta, odnosno interesa za posjet, dobili smo zanimljive odgovore. Odgovore smo prikazali na slici 1. iz kojega se može iščitati disperzija odgovora unutar $10-86 \%$.

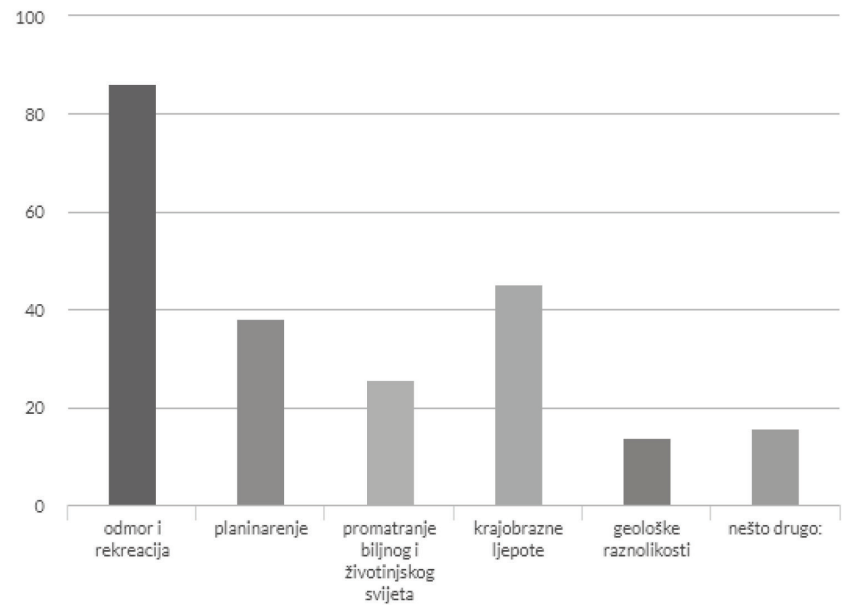

Slika 1. Prikaz odgovora na pitanje o posjetiteljevu razlogu posjeta regionalnom parku (mogućnost više odgovora).

Fig. 1 Overview of answers to the question on visitor's reasons for the visit to the regional park (multiple answers possible). 
A. Vrsaljko i sur.: Krajobrazna i biološka raznolikost kao paradigma razvoja posebnih oblika turizma u regionalnom parku Moslavačka gora

Odgovori sugeriraju da se u parku mogu odvijati Ecotourism, Nature based tourism, Adventure tourism i Wildlife tourism, što se podudara s ekološkim posebnostima parka. Na otvoreno pitanje o razlogu posjeta parku dobili smo zanimljive odgovore (Tablica 1.).

Tablica 1. Prikaz opisnih odgovora ispitanika o razlogu posjeta nacionalnom parku izvan naših standardnih pitanja.

Table 1 Overview of descriptive answers to the question on visitor's reasons for the visit to the regional park, apart from our standard questions.

\begin{tabular}{|l|}
\hline $\begin{array}{l}\text { Aktivno se bavim planinarenjem te smatram da je Moslavačka gora idealan spoj lijepe i } \\
\text { netaknute prirode, zdravog okoliša i mnoštva sadržaja. }\end{array}$ \\
\hline Autentičan ugođaj \\
\hline Direktor sam turističke agencije te sam zainteresiran za međusobnu suradnju. \\
\hline Prekrasno mjesto za opuštanje i bijeg od svakodnevice i užurbanosti grada. \\
\hline Rekreativno hodanje \\
\hline Uživam boraveći u prirodi. \\
\hline $\begin{array}{l}\text { Zaljubljenik sam u prirodu i kao profesor biologije imam veliku želju istražiti ovo područje te } \\
\text { upoznati svoje učenike s njim, a u budućnosti ih dovoditi na organizirane izlete gdje će sami } \\
\text { moći istraživati biljne i životinjske vrste, a istovremeno uživati u ljepotama koje nudi ovaj } \\
\text { prekrasan i netaknut krajolik. }\end{array}$ \\
\hline $\begin{array}{l}\text { Zbog svog zdravstvenog stanja doktor mi je preporučio boravak u prirodi i već godinama biram } \\
\text { Moslavačku goru! }\end{array}$ \\
\hline Boravak u netaknutoj prirodi \\
\hline Preporuka prijatelja \\
\hline S obzirom da sam astmatičarka boravak u prirodi mi odgovara zbog svježeg zraka \\
\hline Tradicijske vrijednosti \\
\hline Uživanje u prirodi
\end{tabular}

Kroz ove odgovore smo dobili potvrdu o značenju biološke, krajobrazne i geološke raznolikosti, a koje bi se mogle svrstati u navedene specifične oblike turizma, uključujući i zdravstveni turizam. Kroz pisane odgovore ostalih posjetitelja iskazano je pozitivno mišljenje o Moslavačkoj gori i svjesnost njezine ljepote, netaknute prirode i boravka na čistom i svježem zraku.

Na pitanje koliko se dana posjetitelji namjeravaju zadržavati u regionalnom parku dobili smo pretpostavljene odgovore, odnosno rezultate. 
A. Vrsaljko i sur.: Krajobrazna i biološka raznolikost kao paradigma razvoja posebnih oblika turizma u regionalnom parku Moslavačka gora

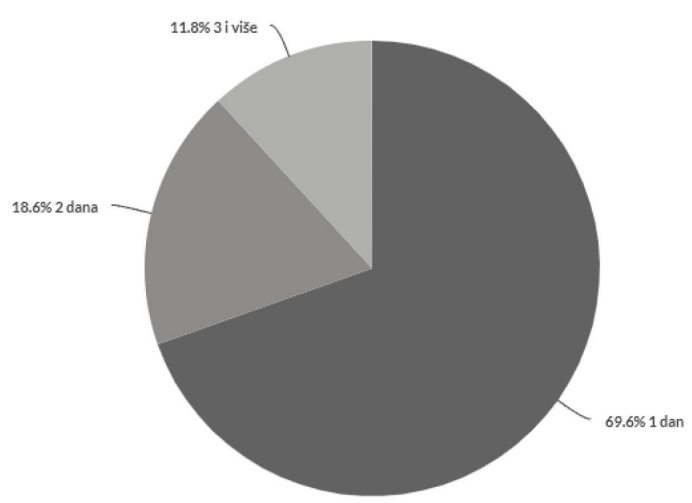

Slika 2. Prikaz odgovora na pitanje koliko dana se posjetitelji namjeravaju zadržati $u$ regionalnom parku.

Fig. 2 Overview of answers to the question how many days visitors plan to stay at the regional park.

Gledajući Sliku 2. ohrabruju podaci da oko 30\% posjetitelja ostaje 2 ili 3 dana. Ovakav rezultat mogli smo pretpostaviti upravo zbog aktivnosti koje regionalni park pruža.

Glede načina informiranja o biološkoj raznolikosti dobili smo zanimljive odgovore (Slika 3).

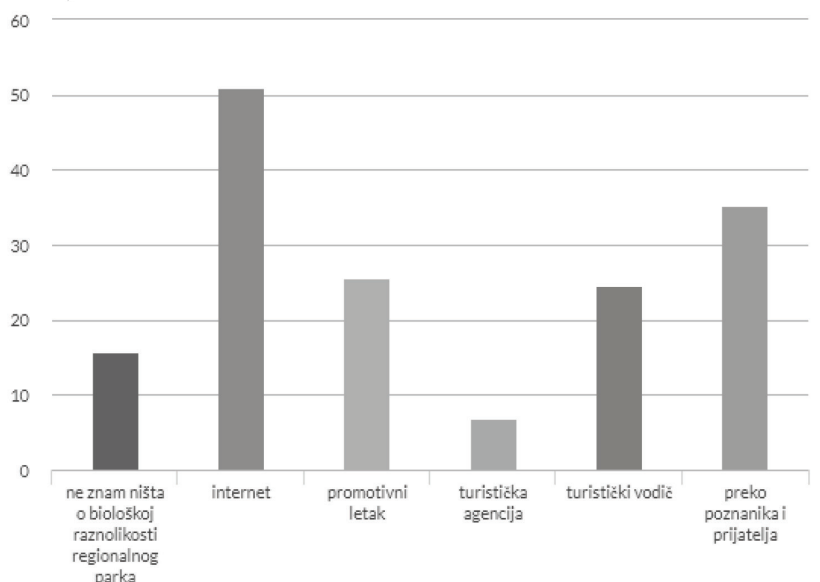

Slika 3. Prikaz odgovora na pitanje o načinu na koji su posjetitelji saznali o biološkoj raznolikosti Moslavačke gore.

Fig. 3 Overview of answers to the question how the visitors got the information on the biodiversity of Moslavacka Gora. 
A. Vrsaljko i sur.: Krajobrazna i biološka raznolikost kao paradigma razvoja posebnih oblika turizma u regionalnom parku Moslavačka gora

Način na koji su posjetitelji upoznati s informacijama o biološkoj raznolikosti govori zapravo o tome koliko znaju o samoj Moslavačkoj gori. Iz navedenog prikaza vidljivo je da većina posjetitelja informacije o biološkoj raznolikosti prikuplja putem Interneta (50\%), prijatelja i poznanika, promotivnog letka ili su informacije dobili od turističkog vodiča. Čak 15\% navodi da ne zna ništa o biološkoj raznolikosti regionalnog parka. Iz ovakvih rezultata može se iščitati kako bi se više truda trebalo uložiti u promotivne materijale koji bi privukli pažnju posjetitelja te bi se svakako trebalo poraditi na promoviranju RP Moslavačka gora putem turističkih agencija.

Slične smo odgovore dobili i o informiranosti o krajobraznoj i geološkoj raznolikosti (Slika 4. i 5.).

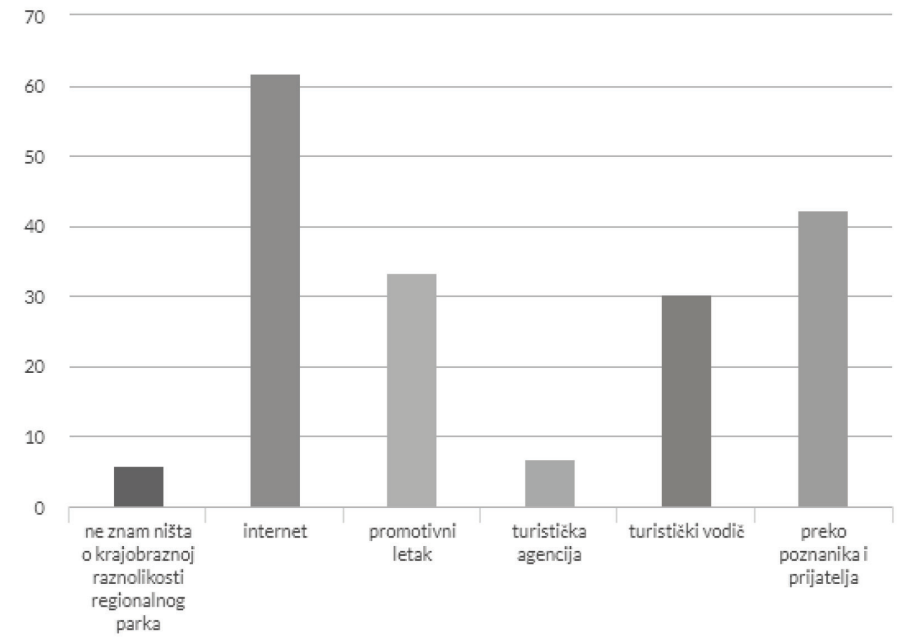

Slika 4. Prikaz odgovora na pitanje o načinu na koji su posjetitelji saznali o krajobraznoj raznolikosti Moslavačke gore.

Fig. 4 Overview of answers to the question how the visitors got the information on the landscape diversity of Moslavacka Gora. 
A. Vrsaljko i sur.: Krajobrazna i biološka raznolikost kao paradigma razvoja posebnih oblika turizma u regionalnom parku Moslavačka gora

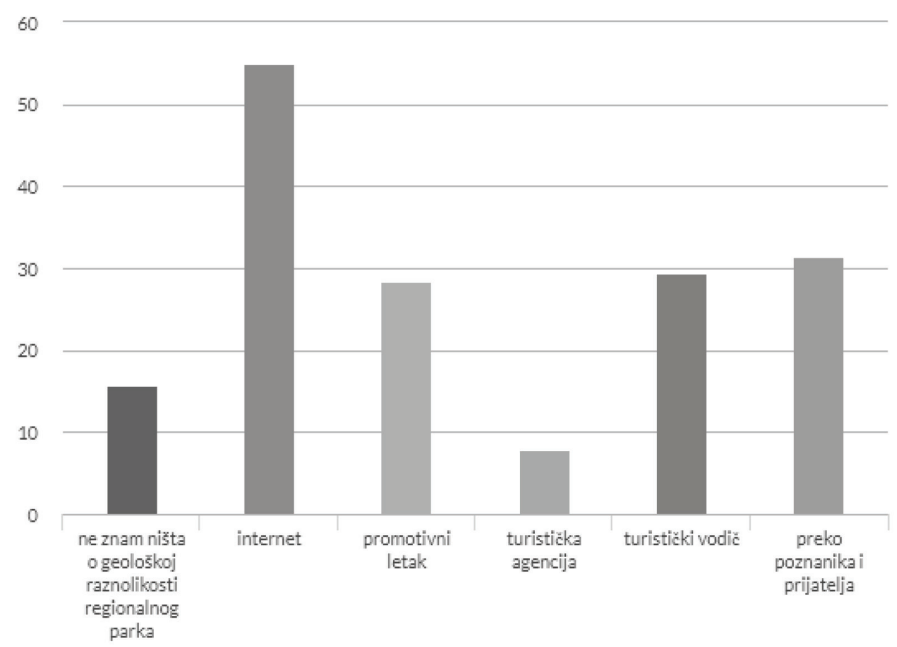

Slika 5. Prikaz odgovora na pitanje o načinu na koji su posjetitelji saznali o geološkoj raznolikosti Moslavačke gore.

Fig. 5 Overview of answers to the question how the visitors learned about the geodiversity of Moslavacka Gora.

Sasvim drugačije odgovore dobili smo nakon posjeta parku o biološkoj, krajobraznoj i geološkoj raznolikosti. Tako je 90,2\% ispitanika odgovorilo da park ima bogatu biološku raznolikost, $97,1 \%$ da ima izuzetnu krajobraznu raznolikost, a $94,1 \%$ da ima bogatu geološku raznolikost. Ovi odgovori nedvosmisleno sugeriraju da se slabo radi na valorizaciji biološke, krajobrazne i geološke raznolikosti parka, odnosno na promidžbi. 
A. Vrsaljko i sur.: Krajobrazna i biološka raznolikost kao paradigma razvoja posebnih oblika turizma u regionalnom parku Moslavačka gora

Na pitanje o tome znaju li posjetitelji da su na Moslavačkoj gori utvrđene 242 biljne vrste, od kojih su 55 zaštićene (5 strogo zaštićenih i 2 ugrožene) posjetitelji su se izjasnili na način prikazan na slici 6.

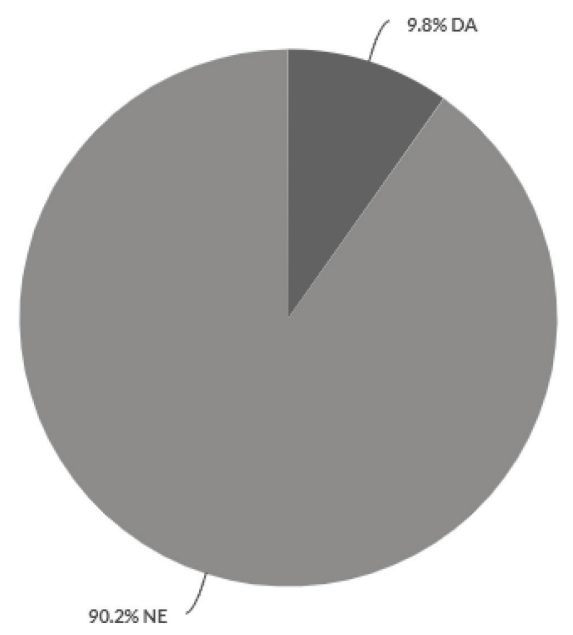

Slika 6. Prikaz odgovora na pitanje o tome znaju li posjetitelji da su na Moslavačkoj gori utvrđene 242 biljne vrste, od kojih su 55 zaštićene

(5 strogo zaštićenih i 2 ugrožene).

Fig. 6 Overview of answers to the question whether visitors know that 242 plant species have been identified in Moslavacka Gora, 55 of which are protected (5 strictly protected and 2 endangered).

Kako se vidi iz Slike 6. dobiveni rezultati su porazni, ako se zna da područja Moslavačke gore nastanjuju 242 biljne vrste, od kojih su 55 zaštićene (5 strogo zaštićenih i 2 ugrožene). Vidljivo je da je tek oko $10 \%$ posjetitelja upoznato sa stvarnim stanjem o tome koliko biljnih vrsta ima na Moslavačkoj gori i koliko životinjskih vrsta obitava na njoj. Dakle, $90 \%$ posjetitelja nije upoznato sa stvarnom biljnom raznolikosti Moslavačke gore, što je i logično jer su različitih interesa, zanimanja i sl., no i tu moraju stručne osobe parka dati veći obol, jer im je to osnovno zanimanje. Slični su rezultati odgovora na pitanje znaju li posjetitelji da na Moslavačkoj gori obitava 155 životinjskih vrsta, gdje samo $11,8 \%$ ispitanika potvrdno ogovara. 
A. Vrsaljko i sur.: Krajobrazna i biološka raznolikost kao paradigma razvoja posebnih oblika turizma u regionalnom parku Moslavačka gora

Nešto bolji odgovori su na pitanje znaju li posjetitelji da je Moslavačka gora uglavnom šumoviti prostor od 15.111.32 hektara s poljoprivrednim površinama i brojnim potočnim dolinama (Slika 7).

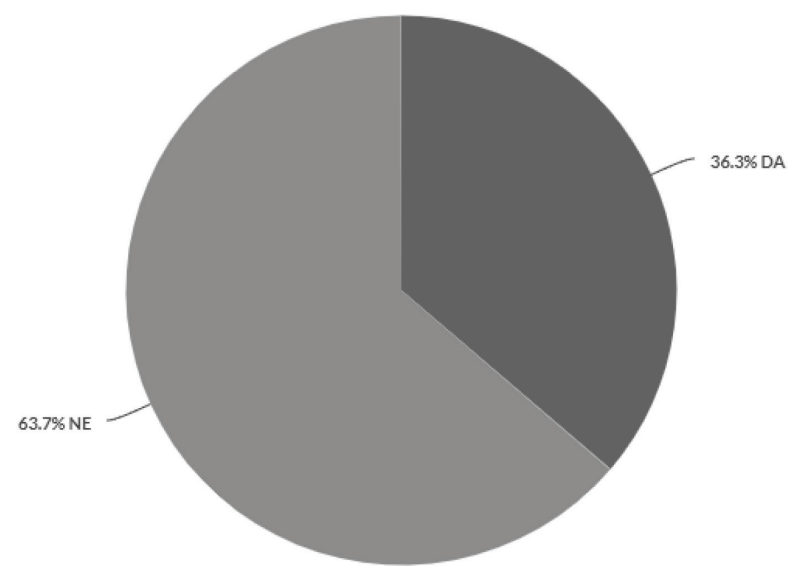

Slika 7. Prikaz odgovora na pitanje o tome znaju li posjetitelji da je Moslavačka gora uglavnom šumoviti prostor od 15.111,32 hektara s poljoprivrednim površinama i brojnim potočnim dolinama.

Fig. 7 Overview of answers to the question whether visitors know that Moslavacka Gora is mainly a forested area of 15111.32 hectares with agricultural land and numerous stream valleys.

Vidljivo je da su posjetitelji malo bolje, iako ne dovoljno upoznati $\mathrm{s}$ krajobraznom raznolikosti Moslavačke gore. Njih skoro 40\% odgovorilo je da zna. Ovakav podatak ukazuje nam na neprepoznatljivost ovog područja te kako bi trebalo poraditi na promidžbi i predstavljanju ovog posebnog područja široj javnosti. Pozitivni odgovori na ovo pitanje su uglavnom od posjetitelja koji su iz šireg moslavačkog kraja, što također ukazuje na nedovoljnu upućenost šire domaće i strane javnosti. 
A. Vrsaljko i sur.: Krajobrazna i biološka raznolikost kao paradigma razvoja posebnih oblika turizma u regionalnom parku Moslavačka gora

Zanimljivi su rezultati odgovora na pitanje o tome znaju li posjetitelji da se na Moslavačkoj gori nalaze različite vrste stijena/minerala, fosila, geoloških i geomorfoloških fenomena (Slika 8).

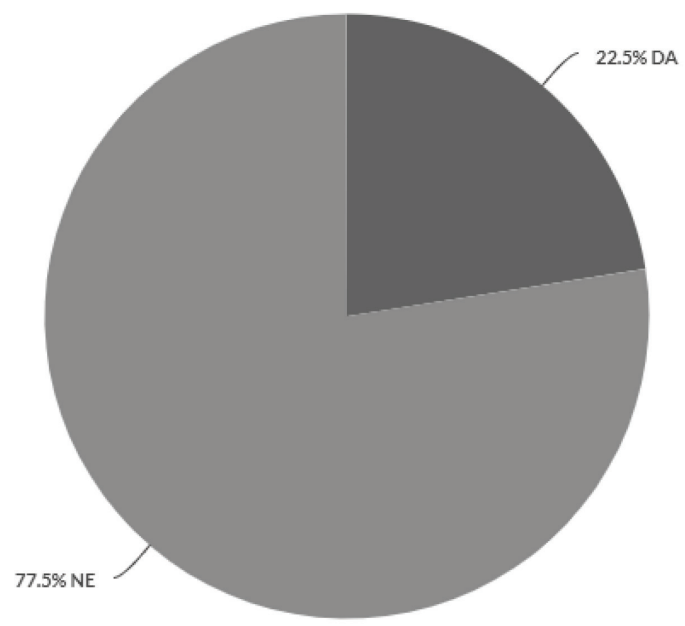

Slika 8. Prikaz odgovora na pitanje o tome znaju li posjetitelji da se na Moslavačkoj gori nalaze različite vrste stijena/minerala, fosila, geoloških i geomorfoloških fenomena.

Fig. 8 Overview of answers to the question whether visitors know that different types of rocks / minerals, fossils, geological and geomorphological phenomena are found in Moslavacka Gora.

Iz prikaza odgovora vidljivo je da tek nešto više od $20 \%$ posjetitelja zna da se na Moslavačkoj gori nalaze različite vrste stijena/minerala, fosila, geoloških i geomorfoloških fenomena. Ovakav postotak je vrlo malen usporedimo li ovaj prikaz s rezultatima koje smo dobili na pitanje o tome ima li Moslavačka gora bogatu geološku raznolikost što dovodi u pitanje poznavanje samog termina geološke raznolikosti.

Iako skoro svi posjetitelji smatraju da Moslavačka gora ima bogatu biološku, krajobraznu i geološku raznolikost, postotak odgovora DA na pitanja o poznavanju stvarne raznolikosti Moslavačke gore je puno manji i ne prelazi $40 \%$ ni na jednom od pitanja. Iz odgovora na pitanja o poznavanju stvarnog stanja raznolikosti vidljivo je da su posjetitelji slabo upoznati $s$ onime što Moslavačka gora nudi. 
A. Vrsaljko i sur.: Krajobrazna i biološka raznolikost kao paradigma razvoja posebnih oblika turizma u regionalnom parku Moslavačka gora

Nakon posjeta parku na pitanje što misle o realnoj biološkoj raznolikosti i smatraju li da ona može pridonijeti razvoju turizma na Moslavačkoj gori, odgovori su iznenađujuće pozitivni (Slika 9.).

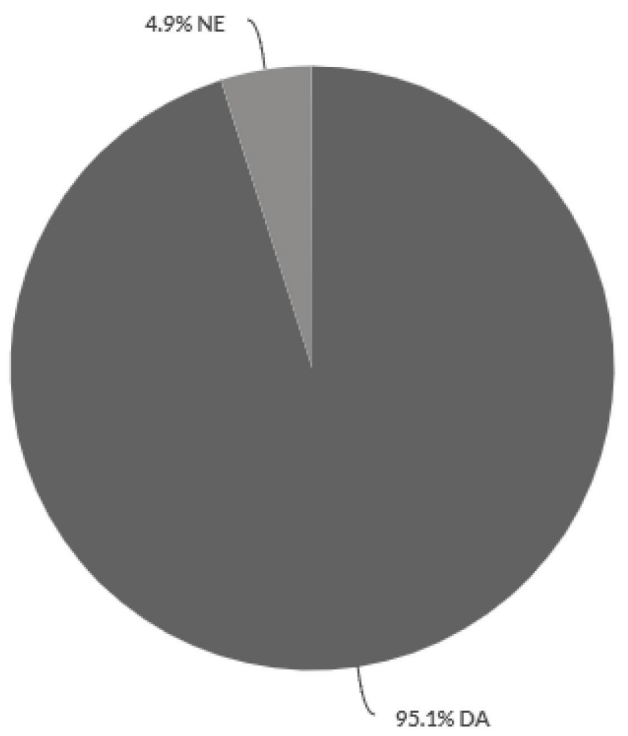

Slika 9. Prikaz odgovora na pitanje smatraju li posjetitelji da realna biološka raznolikost može pridonijeti razvoju turizma na Moslavačkoj gori.

Fig. 9 Overview of answers to the question whether visitors believe that real biodiversity can contribute to the development of tourism in Moslavacka Gora.

Oko $95 \%$ posjetitelja smatra da takva biološka raznolikost može pridonijeti razvoju turizma što je za očekivati nakon odgovara većine da Moslavačka gora ima bogatu biološku raznolikost. Valorizacijom biološkog potencijala mogu se implementirati Wildlife Tourism i Nature based tourism, dijelom i Ecotourism, što bi pridonijelo i samoj promociji parka. 
A. Vrsaljko i sur.: Krajobrazna i biološka raznolikost kao paradigma razvoja posebnih oblika turizma u regionalnom parku Moslavačka gora

Kada je riječ o tome može li realna krajobrazna i geološka raznolikost pridonijeti razvoju turizma na Moslavačkoj gori dobili smo sljedeće podatke (Slika 10.).

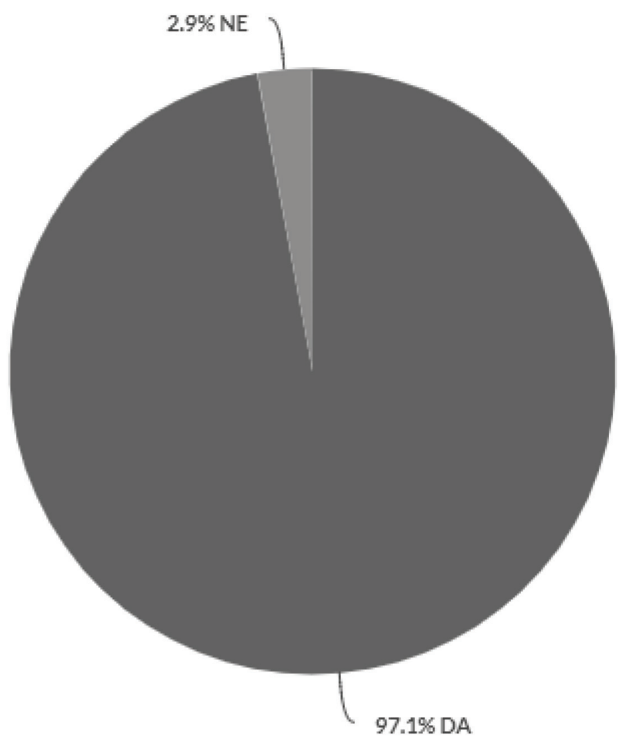

Slika 10. Prikaz odgovora na pitanje smatraju li posjetitelji da realna krajobrazna $i$ geološka raznolikost može pridonijeti razvoju turizma na Moslavačkoj gori.

Fig. 10 Overview of answers to the question whether visitors consider that real landscape and geological diversity can contribute to the development of tourism in Moslavacka Gora.

Iz prikaza jasno možemo vidjeti kako je većina posjetitelja odgovorila pozitivno na pitanje može li krajobrazna i geološka raznolikost pridonijeti razvoju turizma na Moslavačkoj gori. Ovi podaci nam sugeriraju da se temeljem krajobrazne i geološke raznolikosti mogu razvijati posebni oblici turizma kao što su: Adventure tourism, Nature based tourism, Ecotourism, Geotourism, a u rubnim dijelovima, odnosno obiteljskim gospodarstvima, selima i široj okolici Agritourism, Ecoagritourism, seoski turizam i ruralni turizam u svim svojim formama i varijacijama. 
A. Vrsaljko i sur.: Krajobrazna i biološka raznolikost kao paradigma razvoja posebnih oblika turizma u regionalnom parku Moslavačka gora

Nakon prikaza odgovora posjetitelja o tome koliko su upoznati s bogatom raznolikošću parka i njihova mišljenja o razvoju turizma u ovom kraju prikazani su odgovori na pitanja vezana za raznolike aktivnosti koje Moslavačka gora nudi i koje bi još mogla ponuditi da bi se turistički valorizirala. O poznavanju aktivnosti koje mogu prakticirati na Moslavačkoj gori posjetitelji su odgovorili sljedeće.

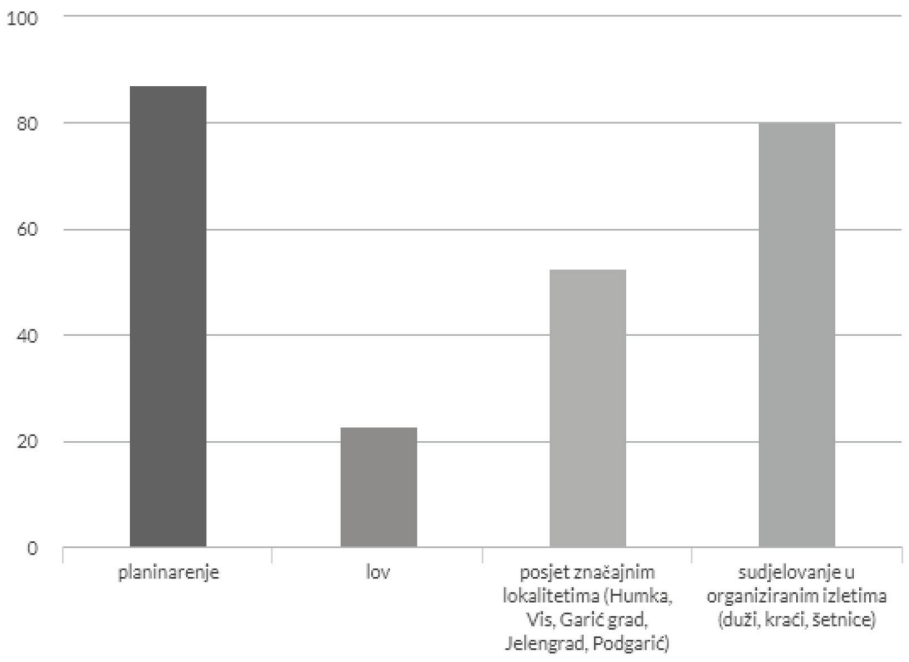

Slika 11. Prikaz odgovora na pitanje o poznavanju aktivnosti koje se mogu raditi na Moslavačkoj gori.

Fig. 11 Overview of answers to the question about the knowledge of activities that can be done in Moslavacka Gora.

Iz Slike 11. vidljivo je da najveći postotak ispitanika zna da na Moslavačkoj gori može planinariti, njih gotovo $90 \%$ (Adventure tourism). Oko $80 \%$ ispitanika zna da na Moslavačkoj gori može sudjelovati u organiziranim izletima koje uključuju šetnice, kraće i duže izlete (Nature Based tourism). Nadalje, oko 50\% posjetitelja upoznato je s time da na Moslavačkoj gori mogu posjetiti značajne lokalitete Humka, Vis, Garić grad, Jelengrad i Podgarić (Ecotourism and Cultural tourism). Tek malo više od $20 \%$ posjetitelja zna da je na Moslavačkoj gori moguć lov (Lovni turizam). Ono što bi svakako trebalo unaprijediti je svijest o kulturno značajnim lokalitetima na ovom području jer je tek $50 \%$ ispitanika upoznato $\mathrm{s}$ tom činjenicom. 
A. Vrsaljko i sur.: Krajobrazna i biološka raznolikost kao paradigma razvoja posebnih oblika turizma u regionalnom parku Moslavačka gora

Slika 12. prikazuje postotak odgovora o mišljenju posjetitelja kakva je interakcija s prirodom na Moslavačkoj gori.

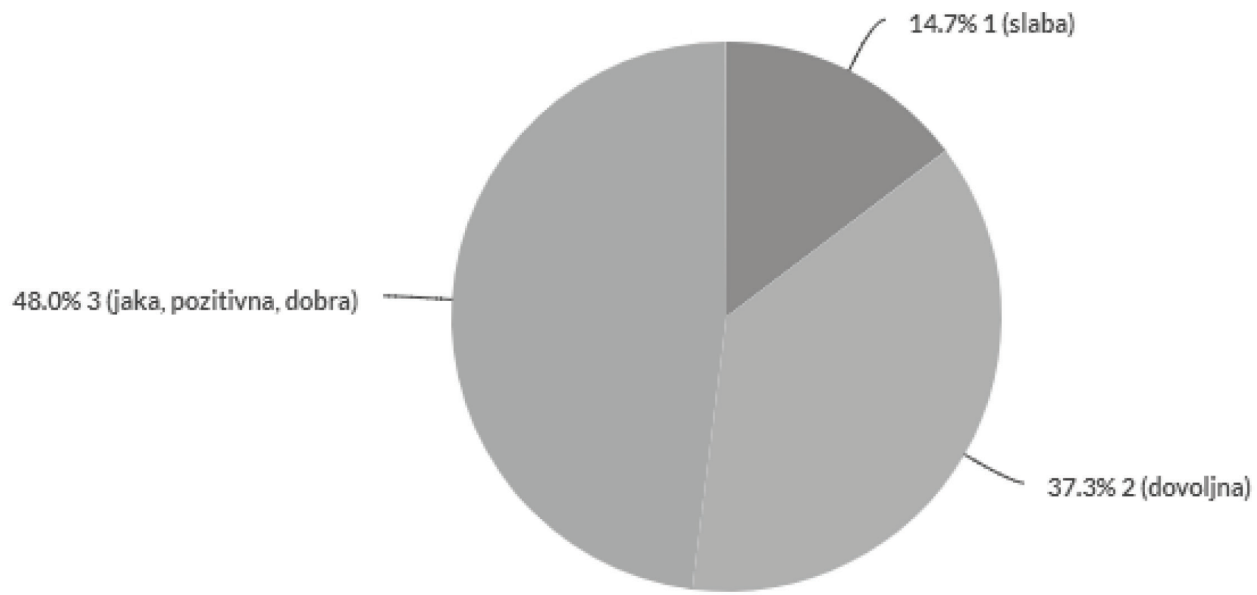

Slika 12. Prikaz odgovora o mišljenju posjetitelja kakva je interakcija s prirodom na Moslavačkoj gori.

Fig 12 Overview of answers on visitors' opinion about the interaction with nature in Moslavacka Gora.

Na slici se može uočiti da $48 \%$ posjetitelja smatra da je interakcija $\mathrm{s}$ prirodom u svrhu razvoja turizma na Moslavačkoj gori jaka, pozitivna i dobra, preko $1 / 3$ da je dovoljna, dok $14.7 \%$ posjetitelja smatra da je ta interakcija vrlo loša. Pri tome valja otkriti gdje su krizne točke i kako ih otkloniti. 
A. Vrsaljko i sur.: Krajobrazna i biološka raznolikost kao paradigma razvoja posebnih oblika turizma u regionalnom parku Moslavačka gora

Nadalje, vrlo je važna interakcija lokalne zajednice s posjetiteljima Moslavačke gore, što možemo vidjeti na Slici 13

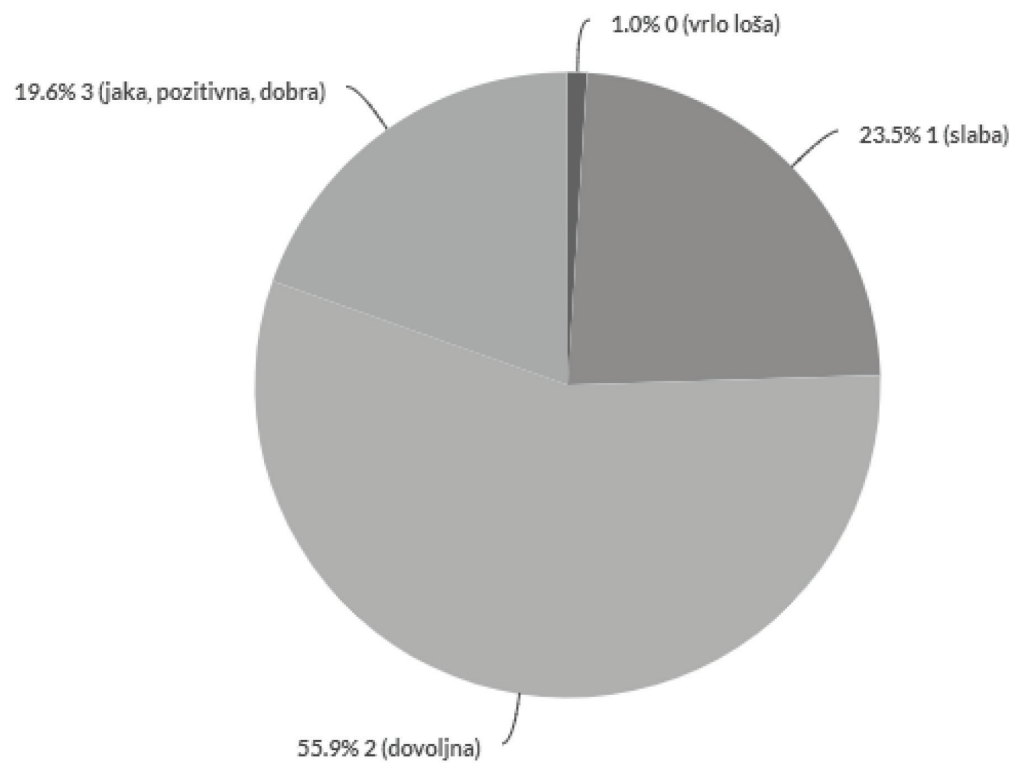

Slika 13. Prikaz odgovora o mišljenju posjetitelja kakva je interakcija lokalne zajednice s posjetiteljima Moslavačke gore.

Fig. 13 Overview of answers about visitors' feedback on how the local community interacts with visitors to Moslavacka Gora.

Iz prikaza odgovora uočava se da oko $76 \%$ posjetitelja smatra da je ta interakcija dovoljna ili jaka, pozitivna i dobra, dok samo 1\% smatra da je ona vrlo loša što je u okvirima novijih istraživanja u svijetu.

Pri kraju ovog upitnika ispitanicima smo omogućili da iskažu svoja mišljenje o oblicima turizma koji bi se mogli implementirati s obzirom na bioraznolikost regionalnog parka, odnosno na geološku i krajobraznu raznolikost parka. 
A. Vrsaljko i sur.: Krajobrazna i biološka raznolikost kao paradigma razvoja posebnih oblika turizma u regionalnom parku Moslavačka gora

Glede biološke raznolikosti ispitanici su se odredili između Ecotourism i Wildlife toursm (Slika 14).

64.7\% Ekoturizam (Ecotourism) uključuje elemente edukacije i očuvanja/zaštite

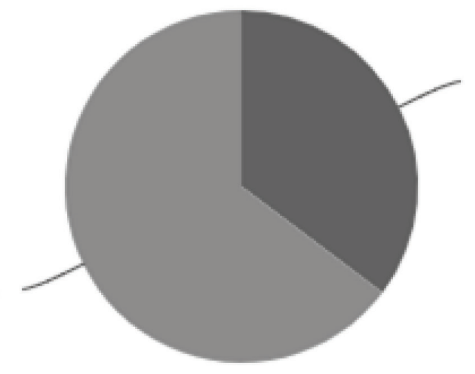

35.3\% Biljni i životinjski svijet u funkciji turizma (Willdife Tourism) - promatranje rijetkih, ugroženih i zanimljivih biljnih ili żivotinjskih vrsta

Slika 14. Prikaz odgovora na pitanje o tome koje aktivnosti bi se mogle razviti kao dio turističke ponude na Moslavačkoj gori s obzirom na biološku raznolikost parka.

Fig 14 Overview of answers to the question about what activities could be developed as part of the tourist offer in Moslavacka Gora with regard to the biodiversity of the park.

Pri tome 65\% ispitanika smatra da obzirom na biološku raznolikost Moslavačke gore treba dati prioritet ekoturizmu, dok ostatak smatra da je takva raznolikost pogodna za razvoj Wildlife tourisma. Potencijali za razvoj Wildlife tourisma su s obzirom na biološku raznolikost koju smo naglasili u uvodnim poglavljima veliki, no očito je da posjetitelji s time nisu adekvatno upoznati. 
A. Vrsaljko i sur.: Krajobrazna i biološka raznolikost kao paradigma razvoja posebnih oblika turizma u regionalnom parku Moslavačka gora

Aktivnosti koje bi se mogle razviti kao dio turističke ponude na Moslavačkoj gori s obzirom na krajobraznu i geološku raznolikost regionalnog parka prikazane su na Slici 15.

61.8\% Avanturistički turizam

(Adventure Tourism) - naglasak na

aktivnosti

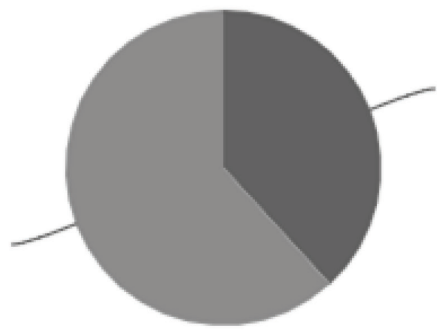

38.2\% Turizam netaknute prirode (Nature Based Tourism) - naglasak na razgledavanju prirodnih krajobraza

Slika 15. Prikaz odgovora na pitanje o tome koje aktivnosti bi se mogle razviti kao dio turističke ponude na Moslavačkoj gori s obzirom na krajobraznu i geološku raznolikost regionalnog parka.

Fig. 15. Overview of answers to the question about the activities that could be developed as part of the tourist offer in Moslavacka Gora considering the landscape and geological diversity of the regional park.

$\mathrm{S}$ obzirom na bogatu krajobraznu i geološku raznolikost oko $62 \%$ posjetitelja smatra da je moguć razvoj Avanturističkog turizma, dok ostali postotak posjetitelja smatra da je moguć razvoj Turizma netaknute prirode 
A. Vrsaljko i sur.: Krajobrazna i biološka raznolikost kao paradigma razvoja posebnih oblika turizma u regionalnom parku Moslavačka gora

Slijedom prethodnih pitanja, a kao završno pitanje predloženi su im edukacijski programi koje bi željeli doživjeti u regionalnom parku prirode Moslavačka gora (grafikon 16).

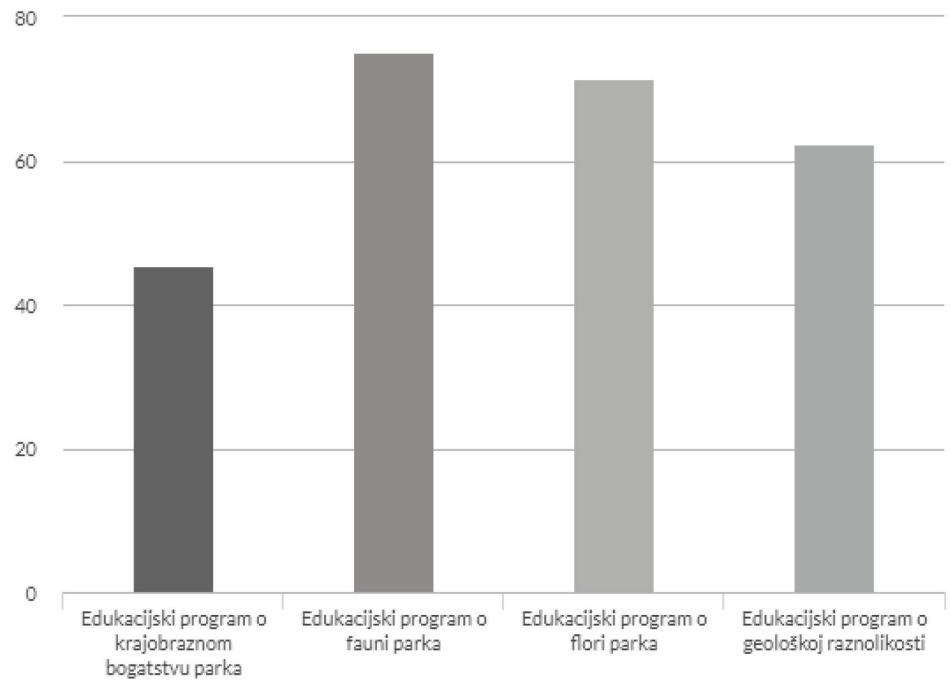

Slika 16. Prikaz odgovora posjetitelj na pitanje koji bi edukacijski program kao dio turističke ponude voljeli doživjeti u regionalnom parku prirode Moslavačka gora

Fig. 16 Overview of visitors' answer to the question which educational program as part of the tourist offer they would like to experience in the Moslavačka Gora Regional Nature Park

Iz prikaza je vidljivo da bi najveći postotak posjetitelja, oko75\%, volio proći edukacijski program o fauni regionalnog parka, oko $70 \%$ posjetitelja edukacijski program o flori, nešto više od $60 \%$ edukacijski program o geološkoj raznolikosti, dok bi oko $50 \%$ posjetitelja voljelo proći edukacijski program o krajobraznom bogatstvu regionalnog parka. Razvidno je da ih više zanima bogatstvo flore $\mathrm{i}$ faune, u odnosu na geološku i krajobraznu raznolikost, te bi slijedom toga trebalo razvijati posebne oblike turizma u parku. Jasno je i vidljivo da se mora raditi na svim edukativnim programima kako bi se adekvatno upoznalo i vrjednovalo moslavački kraj i njegovu baštinu kao paradigmu razvoja navedenih posebnih oblika turizma koji bi se mogli implementirati u ovom zaštićenom području. 
A. Vrsaljko i sur.: Krajobrazna i biološka raznolikost kao paradigma razvoja posebnih oblika turizma u regionalnom parku Moslavačka gora

\section{ZAKLJUČAK}

Zaključno, možemo reći da se moslavački kraj i Regionalni park Moslavačka gora posebno ističu jedinstvenim florističko-faunističkim bogatstvom, krajobraznim bogatstvom i geološkim bogatstvom u cijelom kontinentalnom dijelu Hrvatske. U tom smislu, Moslavinu i Moslavačku goru potrebno je znanstveno i stručno valorizirati kako bi se što bolje zaštitila, očuvala, istražila i unaprijedila.

- Nakon provedenih istraživanja, interpretacije rezultata $s$ diskusijom razvidno je da postoje svi preduvjeti za razvoj posebnih oblika turizma u zaštićenim područjima, kao što su Ecotourism, Wildlife tourism, Adventure tourism, Nature based tourism i dijelom Cultural tourism.

- U rubnim dijelovima Regionalnog parka Moslavačka gora postoje svi uvjeti za razvoj održivih oblika turizma kao što su ruralni turizam, seoski turizam, agriturizam, ekoagriturizam (najviša forma agriturizma i ecoturizma), kulturni turizam, kao i ostali oblici i forme turizma u ruralnim područjima.

Valja upregnuti sve umne, stručne i znanstvene snage da bi se Regionalni park Moslavačka gora stavio u gospodarsku funkciju posebno održivih oblika turizma u zaštićenim područjima.

\section{LITERATURA}

1. Balmford, A., Beresford, J., Green, J., Naidoo, R., Walpole, M. and Manica, A. (2009.): A Global Perspective on Trends in Nature-Based Tourism. Plos Biology 7 (6)

2. Buckley, R. (2004.): Environmental impacts of ecotourism. Wallingford, Oxfordshire, UK: CABI Pub.

3. Cater, E. (1993.): Ecotourism in the third World : Problems for Sustainable Tourism development. Toursm Menagement 85, 90.

4. Cater, E. (2006.): Ecotourism as a western construct. Journal of Ecotourism, 5(1-2), 23-39.

5. Ceballos-Lascurain, H. (1998.): Birdwoching and Ecotourism. The Ecotourism Society Newsletter 1, 1-3.

6. Cifrić, I., (2014.): Očuvanje baštine u kontekstu Europske Unije, ADRIAS sv 20. 
A. Vrsaljko i sur.: Krajobrazna i biološka raznolikost kao paradigma razvoja posebnih oblika turizma u regionalnom parku Moslavačka gora

7. Dutta, D.M., \& Dutta, A. (2013.): A Study on Adventure Tourism as an Emergent Sector in

8. Dutta, D.M., \& Dutta, A. (2013.): A Study on Adventure Tourism as an Emergent Sector in West Bengal. University of Burdwan. Retrieved October 15,2018 from http://shodhganga.inflibnet.ac.in/bitstream/10603/121619/2/02_synopsis.pdf Published: June 30, 2009 https://doi.org/10.1371/journal.pbio.1000144

9. Fennel, D. (2013.): Ecotourism. London: Routledge.

10. Fennel, D. (1999.): Ecotourism: An Introduction. London: Routledge.

11. Frost, W. and Hall, C. M. (2012.): Tourism and National Parks International Perspectives on Development, Histories and Change. Routlege.

12. Gaymans, H. and Hikes, V. (1996.): Five parameters of Ecotourism. The Ecotoursm Equation: Measuring the Impacts, Bulletin 99, 160-169.

13. Granquist SM, Nilsson PA (2016.): Who's watching whom? An interdisciplinary approach to the study of seal-watching tourism in Iceland. Journal of Cleaner Production 111: 471-478.

14. Green, R.J. and Giese, M. (2004.): Negative effects of Wildlife Tourism on Wildlife. In Higginbottom, K. (ed) Wildlife Tourism: Impacts, Management and Planning (pp.81-97). Australia: Common Ground Publishing in association with the Cooperative Research Centre for Sustainable Tourism.

15. Haegeli, P. and Pröbstl-Haider, U. (2016.): Risk in Outdoor Recreation and Nature Based Tourism. Journal of Outdoor Recreation and Tourism, Volume 13, Pages 1-90.

16. Haegeli, Pascal; Pröbstl-Haider, Ulrike (2016.): Research on personal risk in outdoor recreation and nature-based tourism. Journal of Outdoor Recreation and Tourism, April 2016, Vol.13, pp.1-9.

17. Hall, C. M., Müller, D. K., \& Saarinen, J. (2009.): Nordic tourism: Issues and cases. Bristol, U.K: Channel View Publications.

18. Harrison, L. C. and Husbands, W. (1996.): Practising Responsible Tourism: International Case Studies in Tourism Plnning, Policy and Development. New York:John Wiley.

19. Haukeland, J. (2011.): Tourism stakeholders' perceptions of national park management in Norway. Journal Of Sustainable Tourism, 19(2), 133-153,

20. Haukeland, J., Daugstad, K., \& Vistad, O. (2011.): Harmony or Conflict? A Focus Group Study on Traditional Use and Tourism Development in and around Rondane and Jotunheimen National Parks in Norway. Scandinavian Journal Of Hospitality \& Tourism, 1113-37. 
A. Vrsaljko i sur.: Krajobrazna i biološka raznolikost kao paradigma razvoja posebnih oblika turizma u regionalnom parku Moslavačka gora

21. Higginbottom, G. M. A. (2004.a): Sampling issues in qualitative research. Nurse Researcher, 12, 7-19.

22. Holden, A. (2000.): Environment and Tourism. London: Routlledge.

23. Honey, M. (1999.): Ecotourism and Sustainable Development: Who Owns Paradise? Washington DC, USA: Island Press.

http://shodhganga.inflibnet.ac.in/bitstream/10603/121619/2/02_synopsis.pdf

24. Juutinen, A., Mitani, Y., Mäntymaa, E., Svento, R. (2011.): Combining ecological and recreational aspects in national park management: A choice experiment application. Ecological Economics 70(6):1231-1239

25. Lertwannawit, A. and Anuwichanont, J. (2011.): Tourists' Expectation And Perception Towards Environmental Issue Management For Green Tourism Of Khao Yai National Park. International Business \& Economics Research Journal, Volume 10, Number 9, 41-46.

26. McNeely, J. A., Harrison, J. and Dingwall, P. (1994.): Introduction: Pretected areas in the moder world. Protecting nature: Regional Rewiews of Protected Areas (pp 1-28).

27. Newsome, D., Moore, S. A. and Dowling, R. K. (2013.): Natural area tourism: Ecology, impacts and management, second edition.

28. Nikolic, T.; Topic, J. ur. (2005.): Crvena knjiga vaskularne flore Hrvatske. Red Data Book of Vascular Flora of Croatia. Ministarstvo kulture, Državni zavod za zaštitu prirode, Zagreb, 1- 693.

29. Nilsson P-Å (2012.): Tourist Background and Local Acceptance. Akureyri, Iceland: ICTR, University of Akureyri.

30. Reynolds, P.C. and Braithwaite, D. (2001.): Towards a conceptual framework for wildlife tourism. Tourism Management, 22 (1): 31-42.

31. Shaccley, M. (1996.): Wildlife Tourism. London: International Thomas Buisiness Press.

32. Smith, V. L. and Eadinghton, W. R.(1992.): Tourism Alternatives: Potentials and Problems in the DEvelopment of Tourism. Philadelphia: International Academyfor the stady of Tourism, Univeristy of Pennsilvania Press.

33. Vrsaljko, A. and Čukelj, N. (2015.): Natural and Cultural Heritage as a Paradigm for Agrotourism Development in Krapina-Zagorje County. // Agriculturae Conspectus Scientificus. 80 , 4; 229-238

34. Vrsaljko, A. and Viljac, M. (2016.): Comparison of Agritourism in SplitDalmatia County and in Bavaria // Agronomski glasnik. 77, 4-6; 185-206. 
A. Vrsaljko i sur.: Krajobrazna i biološka raznolikost kao paradigma razvoja posebnih oblika turizma u regionalnom parku Moslavačka gora

35. Vrsaljko, A., Turalija, A., Grgić, I. and Zrakić, M. (2017.): Organic Agriculture as a Precondition for Development of Eco-agrotourism on the Islands-a Case Study of Korčula Island. Journal of Central European Agriculture 18 (3), 733-748

36. Wearing, S. and Neil, J. (1999.): Ecotourism: Impacts, Potentials and Possibilites. Oxford: Butterworth-Heinemann. West Bengal. University of Burdwan. Retrieved October 15, 2018 from.

Adresa autora - Author's address:

Anđelko Vrsaljko, Assistant Professor, e-mail: avrsalj@unizd.hr

Teacher Training Department, Mateja Santrić,

Đani Bunja,

Department of Tourism and Communication Studies,

University of Zadar

Franje Tuđmana 24i, 23000 Zadar, Croatia
Primljeno - Received:

16.06.2019. 
A. Vrsaljko i sur.: Krajobrazna i biološka raznolikost kao paradigma razvoja posebnih oblika turizma u regionalnom parku Moslavačka gora 